\title{
Correction to: Habit in Peirce: a Review of Consensus on Peirce's Concept of Habit
}

\section{Marcel Danesi ${ }^{1}$}

Published online: 7 February 2019

(C) Springer Nature B.V. 2019

\section{Correction to: Biosemiotics \\ https://doi.org/10.1007/s12304-018-9334-y}

Please note that the original article with DOI number https://doi.org/10.1007 /s12304-018-9334-y has been corrected.

The copyright holder has changed as the article is no longer an open access article.

Publisher's Note Springer Nature remains neutral with regard to jurisdictional claims in published maps and institutional affiliations.

The online version of the original article can be found at https://doi.org/10.1007/s12304-018-9334-y

Marcel Danesi

marcel.danesi@utoronto.ca

1 University of Toronto, Toronto, Canada 